Cadernos do IL e Cadernos do IL e Cadernos do IL e Cadernos do IL e Cadernos do IL e Cadernos do IL

\title{
AÇÕES DE DIFUSÃO INTERNACIONAL DA LÍNGUA PORTUGUESA
}

\author{
Simone da Costa Carvalho ${ }^{1}$ \\ Margarete Schlatter ${ }^{2}$
}

\begin{abstract}
RESUMO: Situando a língua(gem) no centro da esfera produtiva, a Sociedade do Conhecimento (OLIVEIRA, 2010) está fortemente vinculada à dinâmica do mercado linguístico de diversos países. Este trabalho apresenta um panorama de ações políticas e de planificação linguística relacionadas ao ensino e à promoção internacional do português como língua adicional. Primeiramente, apresentamos os conceitos de política e planificação linguística (HORNBERGER, 2006) e a noção de mercado linguístico (BOURDIEU, 1998). Em seguida, apresentamos ações na área de políticas linguísticas externas, bem como outras iniciativas de promoção da língua portuguesa coordenadas pelo Estado brasileiro, com destaque para o exame Celpe-Bras.
\end{abstract}

PALAVRAS-CHAVE: politica e planificação linguística - português língua adicional - Celpe-Bras

RESUMEN: La sociedad del conocimiento (OLIVEIRA, 2010), que sitúa a la lengua en el centro de la esfera productiva, está estrechamente vinculada con la dinámica del mercado lingüistico en varios países. Este trabajo presenta una visión general de los estudios y acciones políticas y de planificación lingüísticas relacionadas con la educación y la promoción internacional del portugués como lengua adicional. En primer lugar, se introducen los conceptos de política y planificación lingüística (HORNBERGER, 2006) y la noción de mercado lingüistico (BOURDIEU, 1998). A continuación, se presentan acciones en Brasil en el ámbito de las politicas de lenguas, así como otras iniciativas de difusión por parte del Estado, con énfasis en el examen Celpe-Bras.

PALABRAS-CLAVE: política y planificación lingüistica - portugués lengua adicional-Celpe-Bras

\section{INTRODUÇÃO}

Nas últimas décadas temos assistido à tendência crescente de associação de países em blocos e à formação de organismos de cooperação não anglófonos, como BRICS, IBAS, MERCOSUL e UNASUL ${ }^{3}$. Em contrapartida a essas instâncias oficiais,

\footnotetext{
1 Mestranda em Linguística Aplicada no Programa de Pós-Graduação em Letras da UFRGS. simonecc@hotmail.com

${ }^{2}$ Professora do Departamento de Línguas Modernas e do Programa de Pós-Graduação em Letras da UFRGS. margarete.schlatter@gmail.com

${ }^{3}$ BRICS: grupo político de cooperação entre países emergentes formado por Brasil, Rússia, Índia e China. A África do Sul foi incorporada ao grupo em 2011.
}

Cadernos do IL. Porto Alegre, n. ${ }^{\circ} 42$, junho de 2011. p. 260-284. 
atores sociais diversos também têm protagonizado ações nos campos político, social e econômico. De acordo com Oliveira (2010), essa nova organização econômica, denominada Sociedade do Conhecimento, baseia-se na comunicação e na informação, situando a língua(gem) no centro da esfera produtiva. Surgem daí demandas linguísticas que colocam em evidência a necessidade de agir sobre as diversas línguas que circulam no cenário das dinâmicas transnacionais.

No âmbito latino-americano, a criação do MERCOSUL promoveu políticas oficiais em direção à construção de um ambiente bilíngue português-espanhol ${ }^{4}$, impulsionando iniciativas ligadas à cooperação educacional, científica e tecnológica em ambas as línguas ${ }^{5}$. Além de atores e governos da América Latina, por conta do atual crescimento econômico e da projeção brasileira no cenário internacional, cidadãos e instituições de vários países têm investido em aprender português para interagir com interlocutores brasileiros. São indícios desse fato a assinatura de um número crescente de acordos de cooperação educacional firmados entre instituições brasileiras e estrangeiras (especialmente de países latino-americanos, africanos e asiáticos) ${ }^{6}$, $\mathrm{o}$ aumento do número de candidatos que tem prestado o Celpe-Bras (Certificado de Proficiência em Língua Portuguesa para Estrangeiros) e de estudantes de português no exterior ${ }^{7}$. Essas mudanças têm trazido novas demandas para as práticas de ensino e para a pesquisa sobre ensino e aprendizagem do português como língua adicional ${ }^{8}$ (doravante PLA), bem como tem propiciado novas nuances para a representação da língua

IBAS: o Fórum de Dialogo IBAS é uma iniciativa trilateral formada por Índia, Brasil e África do Sul para promover a cooperação Sul-Sul.

MERCOSUL: o Mercado Comum do Sul é uma união aduaneira criada em 1991 por Argentina, Brasil, Paraguai e Uruguai. São países associados: Chile, Bolívia, Peru, Equador, Colômbia e Venezuela (em processo de adesão como país-membro).

UNASUL: a União de Nações Sul-Americanas é formada pelos doze países da América do Sul e tem por objetivo a coordenação política, social e econômica na Região.

${ }^{4} \mathrm{O}$ guarani foi tornado língua oficial do MERCOSUL em 2007. No entanto, as políticas de língua do Bloco têm privilegiado o português e o espanhol, consideradas como "línguas oficiais" desde a assinatura do Tratado de Assunção, em 1991 (CRISTOFOLI, 2010).

${ }^{5}$ Para uma revisão de iniciativas de cooperação educacional, científica e tecnológica no MERCOSUL a partir de 2003, ver Brasil (2011).

${ }^{6}$ Entre 2003 e 2010, 4.300 estudantes de graduação de 20 países africanos, além de 237 pós-graduandos de 14 nações da África vieram estudar no Brasil, principalmente através dos Programas PEC-G E PECPG (ver BRASIL, 2011). Os mesmos programas trouxeram ao país, ao longo da última década, cerca de 2.400 estudantes latino-americanos: 1.173 pelo PEC-G, entre 2001 e 2010, e 1.194 estudantes de PósGraduação, entre 2001 e 2011 (http://www.dce.mre.gov.br/pec/G/historico.html e http://www.dce.mre.gov.br/pec/PG/historico.html).

${ }^{7} \mathrm{Na}$ última década, o número de candidatos do Celpe-Bras passou de 1.155 (2000) para 6.139 (2010). Os centros culturais brasileiros custeados pelo MRE, que em 2004 contavam com cerca de 17,5 mil alunos, em 2010 contavam com 31,7 mil estudantes (FOREQUE, 2011).

${ }^{8}$ De acordo com Schlatter e Garcez (2009), o termo língua adicional (em vez de língua estrangeira ou segunda língua) enfatiza o acréscimo do português a outras línguas que já fazem parte do repertório do indivíduo e também ressalta que, a serviço da comunicação transnacional e/ou da participação cidadã contemporânea, a distinção entre nativo/estrangeiro ou primeira/segunda língua não é relevante. $\mathrm{O}$ uso do termo língua estrangeira será mantido neste trabalho em citações, quando o autor utiliza o termo Português Lingua Estrangeira (PLE).

Cadernos do IL. Porto Alegre, n. ${ }^{\circ}$ 42, junho de 2011. p. 260-284. 
portuguesa, tanto externa quanto internamente 9 . O campo de PLA tem sido pauta também na mídia brasileira ${ }^{10}$, o que nos dá pistas da dimensão que a área vem tomando nas duas últimas décadas.

Este texto tem por objetivos propor a politica e planificação linguística (doravante PPL) como campo teórico necessário para compreender e agir sobre esses novos contextos de demandas linguísticas, e apresentar um panorama de ações de PPL no Brasil para a promoção internacional do português. Buscamos oferecer, tanto a professores e estudiosos da área de PLA quanto àqueles que tenham interesse em língua portuguesa e sua circulação no exterior, uma visão de conjunto de algumas das principais iniciativas que vêm sendo realizadas nesse campo, bem como de pesquisas e referências que possam servir de guia na busca por mais informações para aqueles que desejarem investigar a área mais profundamente.

Para isso, primeiramente, apresentamos os conceitos de política e planificação linguística e o de mercado linguístico. Em seguida, apresentamos um panorama de ações de PPL ligadas à promoção internacional do português e concluímos fazendo uma reflexão sobre essas ações políticas, os avanços na pesquisa sobre o ensino e a aprendizagem de PLA e o status da língua portuguesa.

\section{POLÍTICA E PLANIFICAÇÃO LINGUÍSTICA}

Partindo, nas suas origens, de uma abordagem mais pragmática, técnica e orientada para a solução de problemas linguísticos, a área de PPL estruturou-se sobre dois campos básicos: política e planificação relativas ao corpus (ações ligadas à forma) e relativas ao status (ações relativas à(s) função(ões)) das línguas (HAUGEN, 1966), onde política corresponde à proposta para modificar a realidade linguística, e planificação à implementação dessa proposta. Tal abordagem tomava a língua como dissociada do seu aspecto sócio-histórico, e o planejamento de corpus e de status como ideologicamente neutro (RICENTO, 2000).

Cooper (1989), representante de um momento posterior - caracterizado por uma análise crítica das abordagens sobre pesquisa e implementação de políticas linguísticas (doravante PL) - , discute diversas definições do conceito de PPL, sistematizando-as em função de uma pergunta: "quem planeja o que para quem, e como?" grifos do autor). A partir de tal discussão, o autor delineia sua definição como "políticas linguísticas se referem aos esforços deliberados para influenciar o comportamento de outros no que concerne à aquisição, estrutura ou alocação funcional de seus códigos linguísticos" (ibid., p. 45), ressaltando a noção de agência, isto é, o fato de que os

\footnotetext{
${ }^{9}$ Zoppi Fontana (2009), em pesquisa inserida no campo da História das idéias linguísticas, aponta que a imagem do português como língua transnacional presente em determinados instrumentos linguísticos, como o Exame Celpe-Bras e materiais didáticos de PLA, tem afetado o imaginário brasileiro sobre a língua portuguesa falada no país, conferindo-lhe maior valor.

${ }^{10}$ Ver Guerreiro \& Pereira Junior (2011), Foreque (2011) e Bonino (2007).

11 A tradução deste trecho e de outras passagens originalmente escritas em inglês é de nossa responsabilidade.
} 
esforços podem ser protagonizados por atores sociais diversos, que não o Estado, e em diferentes níveis (regional, local ou para usos específicos). Além disso, o autor introduz as políticas de aquisição ${ }^{12}$ como um terceiro foco da área de estudo, colocando o ensino como objeto da PPL (ibid., p. 33).

Hornberger (2006, p. 28) articula a distinção entre os três tipos principais de PPL da seguinte forma:

políticas de status, como os esforços direcionados à alocação de funções das línguas e letramentos em uma dada comunidade de fala; políticas de corpus como os esforços relacionados à adequação da forma da estrutura das línguas e letramentos; e politicas de aquisição, como os esforços para influenciar a alocação de usuários ou a distribuição de línguas e letramentos, através da criação ou aperfeiçoamento de oportunidades ou incentivo para aprender tais línguas/letramentos, ou ambos. (grifos nossos)

Conforme apontam alguns pesquisadores (ver, por exemplo, GARCÍA \& MENKEN, 2010), a distinção entre os três tipos de PPL é mais clara na teoria do que na prática, e a relação entre as políticas de aquisição, de corpus e de status é simbiótica, podendo as três ocorrerem simultaneamente. Já Calvet (2007) afirma que política/planejamento linguístico "implica ao mesmo tempo uma abordagem científica das situações sociolinguísticas, a elaboração de um tipo de intervenção sobre essas situações e os meios para se fazer essa intervenção" (p. 19). As intervenções podem ser sobre o corpus (a ação sobre a língua), quando se trata de propostas de intervenção sobre a forma, e sobre o status (a ação sobre as línguas), quando é relativa à promoção de determinada língua num contexto de plurilinguismo. Um exemplo de intervenção sobre o status é a chamada indústria das línguas, que corresponde ao investimento que certos países fazem na promoção de uma língua, envolvendo a criação de objetos (dicionários, softwares, bases de dados, etc.) e produtos linguísticos (neologismos, terminologia) num cenário de pesquisa de ponta multidisciplinar ${ }^{13}$ (ibid.).

Depois de tomada uma decisão, a próxima etapa consiste na sua implementação prática. Aos meios que permitem essa implementação, damos o nome de equipamento das línguas, que é composto pela escrita (no caso de línguas ágrafas), pelo léxico (que envolve a criação de neologismos e de terminologias especializadas) e pela padronização (após a promoção de uma língua, ela pode sofrer dialetação e apresentar diferenças na fala, forçando a escolha de um padrão). O caso da padronização tende a ser resolvido de duas maneiras: in vitro, quando o Estado decide qual variedade privilegiar e implementar (de cima para baixo), ou in vivo, quando se cria uma forma intermediária, que abarca as variações sofridas, a partir de uma descrição das variedades dialetais (de baixo para cima).

\footnotetext{
12 Acquisition planning (Cooper, 1989).

${ }^{13}$ Em texto no qual discute as perspectivas do português no contexto internacional, Faraco (2011) faz uma leitura crítica da trajetória e dos interesses envolvidos nos projetos políticos do espanhol e do francês como línguas internacionais, oferecendo, assim, uma visão mais ideológica da indústria das línguas e uma abordagem complementar à de cunho técnico elaborada por Calvet (2007).
} 
Além do equipamento, outro aspecto essencial na implementação de políticas linguísticas é o ambiente linguístico, que corresponde à presença da língua na vida cotidiana de uma comunidade, nas placas, nos anúncios publicitários, nas comunidades sociais na internet, nas campanhas do governo, etc. "É por essa razão que o planejamento linguístico agirá sobre o ambiente, para intervir no peso das línguas, na sua presença simbólica" (ibid., p. 73).

$\mathrm{Na}$ implementação das PL, mudanças são impostas aos falantes, normalmente pelo Estado, através de leis, que são importantes instrumentos do planejamento linguístico. Existem três tipos principais de leis linguísticas: leis que tratam da forma, do uso ou da defesa das línguas (ibid.). As leis que definem a forma podem interferir na escrita e no léxico (por exemplo, fixar regras de ortografia para uma língua em diferentes países, como é o caso do Acordo Ortográfico firmado entre os países da CPLP). As leis que tratam do uso da língua, normalmente lidam com seu status, e definem que língua deve ser usada em determinado momento ou situação (por exemplo, a Lei $n^{0}$ 145/2002 do município de São Gabriel da Cachoeira, no Amazonas, que cooficializou as línguas nhengatu, tukano e baniwa junto ao português naquele município ${ }^{14}$ ); as leis que se ocupam da defesa das línguas podem proteger ou promover uma língua (por exemplo, o Projeto de Lei $\mathrm{n}^{\circ} 156 / 2009$, que institui a obrigatoriedade de traduzir palavras estrangeiras para a língua portuguesa no estado do Rio Grande do $\left.\mathrm{Sul}^{15}\right)$.

Autores como Ricento (2000, 2006) e Hornberger (2006) colocam em discussão a natureza inter e transdisciplinar da PPL:

\begin{abstract}
Sabemos que modelos e abordagens teoricamente adequados precisam considerar a ideologia, a ecologia e a agência ao explicar como e por que as coisas são como são, e ainda avaliar de quem são os interesses e valores que estão sendo atendidos quando PPL são propostas, implementadas e avaliadas. (RICENTO, 2006, p. 6)
\end{abstract}

Desse modo, a PPL tem de lidar com questões como identidade e comportamento linguístico, e deve responder ao desenvolvimento de áreas como a

\footnotetext{
${ }^{14}$ Proposta pelo vereador indígena Camico Baniwa, a Lei foi aprovada no dia 22/11/2002 e determina, entre outros aspectos, que todos os serviços públicos básicos sejam oferecidos nas três línguas cooficiais. No referido município, cerca de $90 \%$ da população é indígena ou descendente de indígenas. Foi a primeira vez na história brasileira que idiomas indígenas ganharam a condição de idiomas oficiais ao lado do português (http://www.novomilenio.inf.br/idioma/20021211.htm e http://www.ipol.org.br/imprimir.php?cod=510).

${ }^{15}$ De autoria do deputado estadual Raul Carrion (PCdoB) (http://www.raulcarrion.com.br/pl156 09.asp. Acesso em 26 out. 2011), esse Projeto de Lei foi aprovado em 19/04/2011 e gerou polêmica junto à população e entre estudiosos da linguagem. Depois de ouvir a opinião de especialistas contra e a favor do Projeto, o governador do RS vetou-o parcialmente, decisão que foi aprovada posteriormente pela Assembléia gaúcha. Dentre os documentos apresentados à autoridade, destacamos o texto Políticas linguísticas para o nosso estado - Carta aberta ao Governador Tarso Genro, elaborado pelos linguistas Ana Zilles e Pedro Garcez. Disponível em: http://www.unisinos.br/_diversos/ju/carta_aberta tarso.pdf. Acesso em 26 out. 2011.
} 
análise do discurso, a etnografia e a teoria social crítica. A Linguística Aplicada, durante um longo tempo, assumiu a PPL apenas em termos de políticas nacionais (nível macro) de educação com vistas a influenciar as práticas linguísticas na sociedade. Apesar de ainda ser esse um grande tema dos estudos na área, é crescente o número de trabalhos que focalizam ações em outros níveis, como o nível microlinguístico, que destaca a apropriação da PL pelos atores durante sua implementação (ver, por exemplo, BALDAUF, 2006 e JOHNSON, 2009). Alguns estudos mais recentes em políticas de aquisição assumem que o professor é um agente central no desenvolvimento de uma PL (GARCÍA \& MENKEN, 2010). Por estarem interligadas, as politicas de aquisição afetam as políticas de corpus e de status, o que torna as ações concebidas na área do ensino essenciais na gestão das línguas/linguagens.

A esse respeito Johnson (2009) afirma que "existe ainda a) uma lacuna na literatura sobre a interpretação e a apropriação de políticas linguísticas educacionais que ilumine conexões entre macro e micropolíticas, e b) escassa orientação metodológica para aqueles que desejam se engajar em tal pesquisa" (p. 139). O autor propõe uma metodologia denominada etnografia de política linguística, que relaciona os níveis micro e macrossociais, comparando análise do discurso crítica das PL com dados etnográficos do contexto local. Seu foco está não apenas na PL enquanto texto, mas principalmente na sua interpretação e apropriação por parte dos atores sociais daquele contexto.

Embora concordemos com García e Menken (2010) em relação à dificuldade de distinguir, na prática, os três tipos de PPL, o panorama apresentado neste artigo centrase em políticas de aquisição. Focalizamos as ações relacionadas ao ensino, ao estabelecimento de parâmetros de proficiência e à pesquisa no cenário nacional e internacional, buscando compreender as possíveis relações dessas ações com o status da língua portuguesa.

\section{O MERCADO LINGUÍSTICO}

Considerando que processos linguísticos estão ligados a processos produtivos, duas perspectivas podem ajudar a compreender as dinâmicas das línguas: a noção de mercado linguístico (BOURDIEU, 1998) e a de Nova Economia (OLIVEIRA, 2010).

A economia das trocas linguísticas (BOURDIEU, 1998) é bastante representativa para explicar o complexo jogo de forças que envolve toda e qualquer relação linguística. Segundo o autor, uma relação de comunicação linguística é essencialmente uma relação de força simbólica, determinada pela estrutura do grupo social em que ocorre a comunicação. A estrutura social é organizada pela troca de bens materiais e bens simbólicos e, consequentemente, pelas relações de força materiais e relações de força simbólicas. A linguagem é considerada um bem simbólico. Assim, as relações de comunicação linguística são relações de força simbólicas ou relações de força linguísticas, que determinam porque, em uma interação verbal, determinados 
falantes exercem domínio sobre outros e certos produtos linguísticos são mais valorizados do que outros (ibid.).

Bourdieu (ibid.) afirma que toda situação de enunciação funciona como um mercado, um mercado linguístico, em que os bens que se trocam são palavras; o falante coloca seus produtos nesse mercado linguístico, prevendo o preço (o valor) que lhes será atribuído. O preço do produto linguístico depende não só do que é veiculado, mas também da posição e da importância que tem, na estrutura social, o grupo a que pertence o falante.

Oliveira (2010) explica a atual configuração do mercado de línguas no mundo como consequência da chamada Sociedade do Conhecimento, ou Nova Economia, que prioriza modelos de acumulação mais flexíveis e centrados na tecnologia e na comunicação. Essa situação de mercado tem apontado para uma nova tendência na gestão das línguas, por parte de atores sociais diversos e também do Estado, que passa a questionar a ideologia monolíngue.

\begin{abstract}
Chama a nossa atenção a velocidade dos processos e a 'nova centralidade' que ganha, no mundo todo, a questão das línguas. Há uma nova pressa e vários países agem com rapidez. Países que nunca trataram da questão das línguas apressam-se em elaborar programas. Países que tradicionalmente são 'clientes' de políticas linguísticas vindas de fora apressam-se em formular seus próprios delineamentos. Oficializam-se novas línguas, reformam-se os sistemas de ensino de línguas estrangeiras, novas línguas lutam para entrar nos curricula, novos e grandes bancos de dados de línguas são montados e financiados. (OLIVEIRA, 2010, p. 22)
\end{abstract}

Sob esse novo paradigma econômico, os bens simbólicos têm altíssimo valor, e é a capacidade de capitalizar o trabalho imaterial que pode determinar a posição dos atores e das instituições nesse mercado. Segundo Oliveira (ibid.), ainda não é possível prever como estará o mercado linguístico no futuro, visto que as mudanças ligadas à tecnologia avançam muito rapidamente e os novos mercados ainda estão sendo mapeados. O autor adverte que o processo de implementação de PL é complexo e lento, levando entre 10 e 20 anos para mostrar resultados considerados significativos.

Protagonizando um mercado linguístico em expansão nas últimas décadas, o Brasil tem fortalecido e ampliado ações de PPL em relação à Língua portuguesa tanto em âmbito nacional como internacional. Passamos, a seguir, a tratar dessas ações, no intuito de apresentar um panorama das iniciativas de promoção da língua portuguesa coordenadas pelo Estado brasileiro e destacando, entre elas, a implementação do CelpeBras.

\title{
CENTROS CULTURAIS DO BRASIL (CCB), INSTITUTOS CULTURAIS BILATERAIS (IC) E LEITORADOS BRASILEIROS ${ }^{16}$
}

${ }^{16}$ Todas as informações e dados apresentados aqui estão em BRASIL-MRE (2011). 
Os CCB, IC e leitorados formam a Rede Brasileira de Ensino no Exterior (RBEx), gerenciada pela Divisão de Promoção da Língua Portuguesa (DPLP) do Ministério das Relações Exteriores (doravante MRE). Todos os CCB e IC são ou estão tornando-se postos aplicadores do Celpe-Bras.

Os CCB constituem o principal instrumento público de promoção do português brasileiro. As atividades estão relacionadas ao ensino do português falado no Brasil, à difusão da literatura brasileira, à organização de espetáculos teatrais, à difusão de música erudita e popular, bem como da cinematografia brasileira, entre outros. Atualmente, existem $21 \mathrm{CCB}: 12$ no continente americano, 3 na Europa e 6 na África.

Os IC são entidades sem fins lucrativos de direito privado e, embora autônomos, cumprem missão em coordenação com as Missões diplomáticas e consulares da jurisdição onde estão sediadas. Os IC estão presentes em Bogotá, Buenos Aires, São José, Caracas, Milão, Montevidéu e Quito.

A rede de leitorados reúne professores especialistas em língua portuguesa, literatura e cultura brasileiras, selecionados pelo MRE e pela Coordenação de Aperfeiçoamento de Pessoal de Nível Superior (doravante CAPES), agência do Ministério da Educação (doravante MEC), atuando em conceituadas universidades estrangeiras. Segundo o Itamaraty, "os Leitorados desenvolvem funções complementares às dos $\mathrm{CCB}$, muitas vezes em regiões nas quais a ampliação da presença cultural brasileira constitui uma das prioridades de nossa política externa, como é o caso da África". Atualmente há 64 leitorados, em 41 países ${ }^{17} 18$.

\section{PROGRAMA DE ESTUDANTES CONVÊNIO DE GRADUAÇÃO (PEC-G) E DE PÓS-GRADUAÇÃO (PEC-PG)}

O PEC-G destina-se a estudantes de países em desenvolvimento com os quais o Brasil mantém acordo de cooperação cultural e/ou educacional e/ou de ciência e tecnologia, que possibilita ao estudante desses países estudar nas Instituições de Ensino Superior (IES) brasileiras. Coordenado pela Divisão de Temas Educacionais do MRE e pela Secretaria de Educação Superior do MEC, o PEC-G foi criado em 1965, com o objetivo de formar recursos humanos de países em desenvolvimento. A África é o continente de origem da maior parte dos estudantes, com destaque para Cabo Verde, Guiné-Bissau e Angola. Na América Latina, a maior participação é de paraguaios, equatorianos e peruanos. Atualmente, são 45 os países participantes (32 efetivos) no PEC-G, sendo 20 da África, 14 da América Central e o Timor Leste, além dos onze vizinhos sul-americanos ${ }^{19}$.

\footnotetext{
${ }^{17}$ Disponível em: http://www.dc.mre.gov.br/lingua-e-literatura/leitorados. Acesso em 28 out. 2011.

${ }^{18}$ Com base em História das Idéias Linguísticas, Diniz (em preparação) analisa a organização e os processos de representação dos diferentes setores da RBEx; Costa (em preparação) investiga como ocorre a formação de docentes em serviço no Instituto Brasileiro-Equatoriano de Cultura.

${ }^{19}$ Fonte: http://www.dce.mre.gov.br/pec/G/historico.html. Acesso em 20 out. 2011.
} 
Por meio do PEC-PG, são oferecidas anualmente vagas em cursos de pósgraduação (Mestrado e Doutorado) em IES brasileiras, incluindo bolsas de estudos de doutorado, oferecidas pela CAPES, e bolsas de mestrado de responsabilidade do Conselho Nacional de Desenvolvimento Científico e Tecnológico (CNPq), agência do Ministério da Ciência e Tecnologia (http://www.dce.mre.gov.br/PEC/PECPG.html). Dentre os objetivos do Programa estão cooperar na formação avançada de nações em desenvolvimento e enriquecer o conhecimento dos professores e estudantes brasileiros de alto nível com as experiências acadêmicas, culturais e de vivência de alunos estrangeiros.

De acordo com Schlatter et al. (2009a) e conforme veremos a seguir, a exigência do exame Celpe-Bras (nível intermediário) como requisito à candidatura aos Programas PEC-G e PEC-PG (resolução do MEC, aprovada pelo Conselho de Reitores de Graduação e pela CAPES em 1999) tem repercussões no número de candidatos do exame e na oferta e nas práticas de ensino para preparação dos estudantes ao CelpeBras.

\section{CERTIFICADO DE PROFICIÊNCIA EM LÍNGUA PORTUGUESA PARA ESTRANGEIROS (CELPE-BRAS)}

O Celpe-Bras foi desenvolvido pelo MEC como um instrumento necessário para lidar com a crescente procura por cursos de graduação e pós-graduação no país, que demandava uma referência de proficiência de língua portuguesa para avaliar a capacidade dos candidatos de participarem nos cenários acadêmicos brasileiros. $\mathrm{O}$ exame é aplicado no Brasil e no exterior com o apoio do MRE. Desde 2009, o INEP (Instituto Nacional de Estudos e Pesquisas Educacionais Anísio Teixeira) é o órgão responsável pelo exame. O Celpe-Bras é exigido pelo Programa de Estudante Convênio para ingresso nas universidades brasileiras, bem como para validação de diplomas de profissionais estrangeiros que pretendem trabalhar no país (por exemplo, o Conselho Federal de Medicina exige o certificado para a inscrição de médicos estrangeiros desde 2001). Dados os diferentes usos, não apenas acadêmicos, dos resultados do exame, o Celpe-Bras pode ser entendido como "uma ação de política linguística mais ampla (...), tornando-o um exame de alta relevância (high stakes) e com maior potencial de impacto" (SCHLATTER et al., 2009a).

O processo de implementação começou em 1993, com a constituição, pelo MEC, de uma Comissão formada por professores e estudiosos de PLA com o objetivo de elaborar um teste padronizado. A primeira aplicação do exame ocorreu em 1998 nas cinco universidades brasileiras então representadas na Comissão Técnica (UFRGS, Unicamp, UFRJ, UFPE e UnB) e em três instituições de países do MERCOSUL (Instituto Cultural Uruguaio-Brasileiro, Centro de Estudos Brasileiros de Assunção e Fundação Centro de Estudos Brasileiros de Buenos Aires). Em 2006, o exame foi aplicado em 19 instituições no Brasil e 33 no exterior, em 26 países, recebendo mais de 4.000 inscrições por ano (SCHLATTER, 2006). De acordo com notícia publicada pelo 
INEP, mais de 7.000 candidatos buscaram a certificação em 2011. Aplicado duas vezes ao ano, o exame contou, em 2011/2, com mais de 4.000 candidatos, 2.261 dos quais provinham de países latino-americanos. Atualmente, a aplicação ocorre em 21 instituições no Brasil e em outros 29 países. Por conta da grande busca por credenciamento de novos postos aplicadores, principalmente no exterior, a previsão do INEP é de que, futuramente, o exame seja aplicado em mais de 100 países $^{20}$.

$\mathrm{O}$ exame tem exercido importante papel na área de PLA, incentivando a busca por formação de professores e orientando a seleção de materiais didáticos e práticas de ensino voltadas para compreensão e produção de texto.

Uma das grandes motivações para a seleção de uma avaliação de desempenho (em vez de um teste de itens isolados de gramática e de vocabulário) foi o potencial de impacto no ensino e na aprendizagem de PLE, que por muitos anos se limitou a práticas exclusivamente estruturalistas, materiais didáticos e aulas focalizadas em regras gramaticais, vocabulário e exercícios de preenchimento de lacunas. Alguns estudos (...) mostram que já se faz sentir uma mudança considerável na procura por formação de professores (...), no aumento de alunos estudando Português nesses postos (...), na elaboração de novos materiais didáticos (que passam a incluir textos autênticos de revista, jornais, textos em vídeo e em áudio) e na mudança de práticas de ensino, que se voltam para o uso da língua portuguesa para comunicação oral e por escrito, levando-se em conta o contexto da interação, ao invés de focalizar exclusivamente conhecimento sobre a língua (SCHLATTER, 2006, p. 175, grifo da autora).

O Celpe-Bras e seus impactos têm sido tema de vários trabalhos de pesquisa acadêmica. Dentre os assuntos pesquisados estão a validade e a confiabilidade do exame, o nível de complexidade das tarefas, o efeito retroativo do exame e seus impactos no ensino de PLA, a relação do exame com práticas e eventos de letramento, e a análise do exame como instrumento de política linguística e promoção do português ${ }^{21}$ 22. Esses estudos constroem um novo campo de pesquisa no Brasil (avaliação na área de línguas adicionais), reunindo profissionais de diferentes IES brasileiras e abrindo possibilidades de intercâmbios acadêmicos em um cenário mais amplo no Brasil e no exterior. Um dos grandes incentivadores para esse intercâmbio tem sido a reunião de

${ }^{20}$ Disponível em: http://portal.inep.gov.br/visualizar/-/asset_publisher/6AhJ/content/america-latina-temo-maior-numero-de-participantes-no-celpe-bras?redirect $=\mathrm{http} \% 3 \mathrm{a} \% 2 \mathrm{f} \% 2 \mathrm{fportal}$.inep.gov.br $\% 2 \mathrm{f}$. Acesso em 28 out. 2011.

${ }^{21}$ Por exemplo, Schoffen (2009) trata da validade de construto do Celpe-Bras focalizando a grade de avaliação da produção escrita; Fortes (2009) analisa a avaliação da entrevista oral sob uma perspectiva etnometodológica; Gomes (2009) pesquisa os níveis de complexidade das tarefas; os impactos do exame no ensino são discutidos em Scaramucci (2006), Schlatter (2006), Rodrigues (2006) e Schlatter et al. (2009a), enquanto Li (2009) analisa os impactos na preparação dos candidatos.

${ }^{22}$ Zoppi Fontana (2009) insere a criação do exame como um dos acontecimentos linguísticos do "novo período de gramatização brasileira" iniciado nos anos 90, analisando-o como evento que colabora para ressignificar o lugar da língua brasileira no mundo, visto que esses novos significados se refletem e materializam nas práticas de políticas linguísticas governamentais e também em práticas da sociedade civil, como no campo editorial e acadêmico. 
professores de diferentes IES e, mais recentemente, também dos CEB e IC, para a correção do exame. Esses encontros, de uma semana, duas vezes ao ano, promovem, além de oportunidades para o debate e trocas de ideias e informações, a formação continuada de profissionais de PLA a respeito dos pressupostos teóricos do exame. Essa ação continuada torna-se, assim, terreno fértil para a atualização e mudanças nas práticas de ensino e na elaboração de materiais didáticos e para possíveis parcerias de pesquisa na área.

É importante ressaltar ainda o fato de a experiência do exame ter servido de base para a elaboração de dois outros instrumentos de avaliação de proficiência no que se refere aos pressupostos teóricos, visão de linguagem, objetivos, formato $\mathrm{e}$ implementação: o Certificado de Proficiência em Libras, no Brasil, e o Certificado de Español - Lengua y Uso (CELU), na Argentina. O CELU vem sendo aplicado desde 2004 e foi concebido como fruto da colaboração entre a comissão acadêmica argentina responsável pelo exame e a comissão técnica do Celpe-Bras, utilizando a mesma tecnologia do exame brasileiro. Segundo Schlatter et al. (2009a),

\begin{abstract}
busca-se nortear mudanças no ensino e definir parâmetros de proficiência em uso da língua ao invés de conhecimento sobre a língua. Além disso, busca-se afirmar as variedades brasileira e rio-platense na elaboração de instrumentos de avaliação de proficiência em língua portuguesa e espanhola em contextos de intercâmbios acadêmicos e econômicos entre o Brasil e a Argentina (p. 95).
\end{abstract}

Ao discutir as consequências do Celpe-Bras e do CELU nos contextos de ensino brasileiro e argentino, as autoras afirmam que os exames são parâmetros de referência para o desenvolvimento de currículos e de materiais didáticos e têm promovido a atualização dos professores (ibid., p. 111-112). O primeiro ponto diz respeito à mudança gradual nas metodologias de ensino percebidas principalmente através de pesquisas feitas sobre o efeito retroativo do Celpe-Bras (ver, por exemplo, SCARAMUCCI, 2006 e LI, 2009, entre outros). O segundo, refere-se à necessidade dos professores de português e de espanhol de conhecerem os critérios de avaliação e a noção de uso de linguagem que embasa os exames tanto para participar da aplicação e da equipe de correção dos exames como para preparar seus alunos.

\title{
GRUPOS DE ENSINO E PESQUISA DE PLA NO BRASIL
}

Como vimos, o advento e os impactos do exame Celpe-Bras têm gerado várias discussões a respeito de práticas de ensino na área de PLA e incentivado pesquisas sobre ensino, aprendizagem e avaliação nesse campo ${ }^{23}{ }^{24}$. Dentre os grupos de ensino e

\footnotetext{
${ }^{23}$ A mídia também tem veiculado notícias sobre o crescimento da demanda de ensino de PLA em instituições privadas. No entanto, não é objetivo deste texto apresentar esse setor.

24 Estamos tratando aqui de ensino de português para estrangeiros. Outros grupos que trabalham com ensino/pesquisa de PLA em comunidades indígenas, grupos de imigração e comunidades surdas, por conta das limitações de espaço, não são tema deste trabalho.
} 
pesquisa em PLA no Brasil, a Universidade de Brasília (UnB), a Universidade Estadual de Campinas (Unicamp) e a Universidade Federal do Rio Grande do Sul (UFRGS) reúnem equipe com larga experiência na área.

$\mathrm{Na}$ UnB foi criado, em 1997, o primeiro curso de graduação em PLA (Português do Brasil como segunda língua: http://vsites.unb.br/il/liv/graduacao/pbsl.htm). A universidade é pioneira na integração de ensino, pesquisa e extensão no Programa de Ensino e Pesquisa em Português para Falantes de Outras Línguas (PEPPFOL), oferecendo aulas à comunidade estrangeira e alunos conveniados, além de projetos de Formação Inicial Continuada para alunos do curso de Letras da UnB (http://www.let.unb.br/peppfol/). Atuando também na área de Pós-Graduação, o foco de pesquisa é a formação de professores.

Semelhante proposta é desenvolvida pelo Programa de Português para Estrangeiros (doravante PPE) da UFRGS ${ }^{25}$, criado em 1994, que tem como um de seus principais objetivos a formação de professores-pesquisadores através da reflexão de suas práticas docentes e de desenvolvimento de pesquisa sobre práticas de ensino e de avaliação. O Programa mantém o Seminário de Formação de Professores, com encontros semanais, desde o ano de sua criação. Diversos trabalhos de pesquisa têm sido realizados nesse grupo em nível de graduação e pós-graduação, relacionados à produção de materiais didáticos, ao Celpe-Bras e, mais recentemente, a práticas de ensino e de avaliação a distância ${ }^{26}$.

A Unicamp, também pioneira no Brasil em ensino, elaboração de materiais didáticos e pesquisa na área, atualmente oferece ensino de PLA através do Centro de Ensino de Línguas, que se constitui também como espaço institucional para pesquisa voltada ao ensino de línguas, mantendo vínculo acadêmico com o Departamento de Linguística Aplicada do Instituto de Estudos da Linguagem (http://www.cel.unicamp.br/index.php?

option $=$ com_content\&view=article\&id=89\&Itemid=498). Além disso, a universidade se destaca pela pesquisa na área de impactos do exame Celpe-Bras ${ }^{27}$.

\footnotetext{
${ }^{25}$ A título de exemplo, apresentamos o número de alunos no PPE nos últimos cinco anos: 256; 254; 278; 321 e 372 . No semestre 2011/2, o programa conta com mais de 20 professores (estagiários de graduação e pós-graduação) ministrando 26 cursos para 209 alunos estrangeiros de cerca de 30 países (dados obtidos junto à Coordenação-PPE/UFRGS).

${ }^{26}$ A pesquisa "Celpe-Bras/Parte Coletiva: ponto de corte dos níveis de certificação (Nível Intermediário) e não certificação (Nível Básico)", coordenada por Margarete Schlatter de 2003 a 2010, reuniu um grupo de pesquisadores que investigou principalmente questões de validade do exame. Algumas das dissertações e teses desenvolvidas por esse grupo são Sidi (2002), Schoffen (2003), Gomes (2009), Fortes (2009), Li (2009), Schoffen (2009). Outras pesquisas sobre ensino, avaliação e materiais didáticos são Ohlweiler (2006), Bulla (2007), Santos (2007), Yan (2008), Bortolini (2009), Andrighetti (2009), Ramos (2010). Atualmente, o grupo desenvolve pesquisa em "Práticas pedagógicas em ambiente informatizado" (ver também seção deste artigo sobre o CEPI).

${ }^{27}$ Ver projetos de pesquisa coordenados por Matilde V. R. Scaramucci: "Impactos sociais da avaliação em contextos de ensino/aprendizagem de língua estrangeira/segunda língua (Português e Inglês)" (CNPq, 2005-2008) e "Validade e impactos sociais da avaliação em contextos de línguas diversos (Português LM/L2 e Inglês LE)" (CNPq, 2008-2011).
} 
Um dos requisitos das instituições credenciadas para aplicar o exame ${ }^{28}$ é oferecer cursos de PLA. Isso quer dizer que atualmente a grande maioria das IES brasileiras oferece cursos de português para estrangeiros e várias delas recebem candidatos ao PEC-G para prepará-los para o Celpe-Bras. Além das IES mencionadas anteriormente, há várias que têm uma caminhada consolidada no ensino e que reúnem grupos de pesquisa em andamento ${ }^{29}$, tais como: PUC-SP (através do NUPPLE), PUC-RJ, UFBA (através do PROPEEP), UFF, UFMG, UFPR (através do CELIN), UFRJ, UFSC. Dentre as que iniciaram mais recentemente na área de pesquisa em PLA estão: UEL (através do Laboratório de Línguas-IRCH), UFAM, UFSCar, UNIPAMPA, UNESP e USP.

Esses grupos de ensino e pesquisa têm atuado como pólos de formação de professores e elaboração de materiais didáticos ${ }^{30}$. Como vimos, tais atividades são relevantes para a PPL, pois as decisões de quais serão as práticas pedagógicas e como serão implementadas recai, no nível microlinguístico, sobre as equipes de trabalho (quando o grupo/coordenação pedagógica define linhas de ação) e também sobre o professor, através do modo como se apropria das diretrizes estabelecidas e faz uso do material didático. Além disso, através da confecção de material didático - produtos linguísticos centrais nas políticas de aquisição -, estão sendo difundidas e sistematizadas determinadas práticas pedagógicas e perspectivas de língua(gem $)^{31}$.

$\mathrm{Na}$ área de publicações no campo de ensino/aprendizagem de PLA, temas como a elaboração e o uso de materiais didáticos, pedagogia de projetos, o ensino de PLA para falantes de línguas próximas e distantes, o ensino a partir de uma abordagem sociocultural têm sido foco de publicações e pesquisas de conclusão de curso, mestrado e doutorado ${ }^{32}$.

\footnotetext{
${ }^{28} \mathrm{~A}$ lista das universidades brasileiras credenciadas para aplicar o exame Celpe-Bras pode ser acessada no site do INEP: http://portal.inep.gov.br/postos-aplicadores. Acesso em 7 nov. 2011.

${ }^{29}$ Os grupos de pesquisa na área de PLA podem ser conferidos na Plataforma Lattes, através de uma busca em http://dgp.cnpq.br/buscagrupo/.

${ }^{30}$ A maior parte desse material é restrito ao próprio uso dos grupos de trabalho, não alcançando o mercado editorial. Como afirmam Schlatter et al. (2009a, p. 111), "a influência dos exames em livros didáticos (publicados) ainda pode ser considerada tímida".

${ }^{31}$ Zoppi Fontana (2009) e Diniz (2009) discutem o processo de instrumentação da língua portuguesa através da produção de material didático de PLA, apontando o deslocamento da posição de autoria que esse processo de construção de instrumentos linguísticos tem causado.

${ }^{32}$ Para um panorama das pesquisas e publicações até o ano de 2007, ver Carvalho (2007). Dentre alguns dos trabalhos acadêmicos posteriores, Andrighetti (2009) discute a elaboração de tarefas de compreensão oral para níveis iniciais; Furtoso (2011) avalia o desempenho oral em contexto online enquanto Simões (em preparação) investiga o ensino de PLA em ambientes virtuais; o ensino de leitura e escrita no mundo dos negócios é tema de Duarte (2009); Coelho de Souza (em preparação) estuda a canção popular brasileira no ensino de PLA. Sob uma perspectiva etnometodológica, Ramos (2010) relaciona convites à participação e momentos desconfortáveis em sala de aula de PLA; Yan (2008) elabora proposta de unidade didática para alunos chineses com base na noção de gêneros do discurso. Na área de formação de professores de PLA, destacamos as publicações de Mendes (2011) e Furtoso (2009).
} 


\section{COMUNIDADE DOS PAÍSES DE LÍNGUA PORTUGUESA (CPLP) E 0 INSTITUTO INTERNACIONAL DA LÍNGUA PORTUGUESA (IILP)}

A CPLP foi criada em Lisboa, em 1996, com a finalidade de reunir os sete países lusófonos (Brasil ${ }^{33}$, Angola, Cabo Verde ${ }^{34}$, Guiné-Bissau, Moçambique, Portugal e São Tomé e Príncipe) em torno de três objetivos gerais: a articulação político-diplomática entre os seus membros; a cooperação econômica, social, cultural, jurídica e técnicocientífica; e a promoção e difusão da língua portuguesa (doravante LP). Atualmente, Timor-Leste também compõe a CPLP. Entre os observadores-associados estão Guiné Bissau, Ilhas Maurício e Senegal (http://www.cplp.org/id-115.aspx).

Uma das ações de PPL discutidas no âmbito da CPLP foi o Acordo Ortográfico, assinado em 1990 pelos estados membros e que entrou em vigor no Brasil em 2009. O objetivo do Acordo é unificar as duas ortografias oficiais existentes, criando uma base comum que trabalhe como um instrumento linguístico, favorecendo uma maior circulação de materiais produzidos em português, incluindo textos literários e livros didáticos, por exemplo. Tais aspectos favoreceriam tanto a formação de uma cultura de letramento quanto a abertura de um mercado editorial não dividido por duas grafias oficiais $^{35}$.

Criado em 2002 e sediado em Cabo Verde, o IILP é identificado como o primeiro instrumento institucional da CPLP, representando os oito países-membros de forma paritária e tendo como objetivos fundamentais "a promoção, a defesa, o enriquecimento e a difusão da língua portuguesa como veículo de cultura, educação, informação e acesso ao conhecimento científico, tecnológico e de utilização oficial em fóruns internacionais" (http://www.iilp.org.cv/index.php? option $=$ com content\&view $=$ article $\& i d=49 \&$ Itemid $=27$ ).

Se, por um lado, refletindo sobre uma trajetória anterior de não-articulação e insucesso do Instituto, Faraco (2008) afirmou que a instituição "não existe na prática", hoje é possível perceber uma mudança significativa nas diretrizes de ação do IILP, que tem adotado uma posição audaciosa e inovadora de difusão global do português desde 2010. “O IILP é um aparelho muito novo, não como Instituição, mas sim enquanto idéia

\footnotetext{
${ }^{33}$ Ao investigar a história linguística do Brasil Meridional no período de 1750 a 1830, Oliveira (2004) faz uma análise epistemológica da forma como foi construída a história da língua portuguesa no Brasil e observa as periodizações propostas para essa história, discutindo sua relação com a produção de conhecimento e as ações ligadas às políticas de língua no país.

${ }^{34}$ Torquato (2009) investiga as políticas linguísticas em Cabo Verde, analisando as ações implementadas desde o período colonial até 2006.

${ }^{35}$ Grayley e Caetano (2011) avaliam as ações da CPLP três anos após o estabelecimento da meta, em 2008, de internacionalizar o português. Afirmam que o avanço foi mínimo e que o Acordo Ortográfico ainda "engatinha" na maioria dos países da CPLP. Os autores ressaltam a necessidade de aumentar a presença do português nas organizações internacionais e de ter mais professores leitores em universidades estrangeiras.
} 
de gestão da língua"36 37, afirma Gilvan Muller, diretor-executivo do IILP no biênio 2010-2012.

Atualmente, o português é a quinta língua mais falada no mundo. Em Portugal, as atividades ligadas ao idioma correspondem a $17 \%$ do PIB $^{38}$. É também a quinta língua do mundo em número de usuários na Internet ${ }^{39}$. O IILP, em sua nova diretriz, quer inserir o português num lugar de destaque no mercado linguístico, tirando vantagem desses números. Um dos projetos em curso é a elaboração do Vocabulário Ortográfico Comum (VOC) que deve constituir um instrumento linguístico comum aos países de língua portuguesa, abrangendo léxico de áreas especializadas.

Em 2010, foi concluída a revisão dos Estatutos do IILP, que buscam torná-lo um instrumento mais eficaz de promoção de políticas comuns e nacionais em relação à difusão do português. A $1^{\text {a }}$ Conferência Internacional sobre o Futuro da Língua Portuguesa no Sistema Mundial, realizada em Brasília (abril/2010), forneceu ao IILP uma pauta concreta de trabalho até 2012, através do Plano de Ação de Brasília para a Promoção, a Difusão e a Projeção da Língua Portuguesa ${ }^{40}$. Atualmente estão em andamento quatro colóquios para discutir linhas de ação da entidade até 2012: Colóquio de Maputo (set. 2011), sobre a diversidade linguística na CPLP; Colóquio Internacional da Praia sobre a Língua Portuguesa nas Diásporas (nov. 2011); colóquio para discutir a unificação do português na Internet (previsto para 2012, Fortaleza); colóquio de Luanda (previsto para 2012) para discutir o português como língua de trabalho nas organizações internacionais.

\section{POLÍTICAS DE PROMOÇÃO DA(S) LÍNGUA(S) NO MERCOSUL ${ }^{41}$}

Desde a criação do Setor Educacional do MERCOSUL (SEM), reconheceu-se a importância da educação como estratégia para o desenvolvimento da integração econômica e cultural do Bloco. O Plano de Ação 2011-2015 ${ }^{42}$ inclui dentre suas metas

\footnotetext{
${ }^{36}$ Fonte: CAMARGO, Bárbara. "A língua é de quem se apropria dela e gere" - Entrevista com Gilvan Müller. Kriolidadi Suplemento Cultura. Cabo Verde, 03/06/2011. Disponível em http://iilp.files.wordpress.com/2011/06/caderno-kriolidadi.pdf. Acesso em 22 out. 2011.

${ }^{37}$ Faraco (2008) discute as ações da CPLP/IILP, e posteriormente analisa o IILP sob nova perspectiva (id., 2011). O autor (2011) destaca o desenho efetivamente internacional do Instituto, um modelo diferente do praticado tradicionalmente por institutos de língua.

${ }^{38}$ Fonte: $O$ valor econômico da língua, 2007. Disponível em http://www.instituto-camoes.pt/encartejl/1018-lingua-portuguesa-representa-17-do-pib. Acesso em 22 out. 2011.

${ }_{39}$ Fonte: Internet World Users by Language, 2011. Disponível em http://www.internetworldstats.com/stats7.htm. Acesso em 22 out. 2011.

${ }^{40}$ Disponível em http://observatorio-lp.sapo.pt/pt/temas-de-actualidade/plano-de-acao-de-brasilia-para-apromocao-a-difusao-e-a-projecao-da-lingua-portuguesa. Acesso em 22 out. 2011.

${ }^{41}$ O Mercado Comum do Sul foi criado em 1991, com a assinatura do Tratado de Assunção por Argentina, Brasil, Paraguai e Uruguai. São países associados: Chile, Bolívia, Peru, Equador, Colômbia e Venezuela (em processo de adesão como país-membro).

${ }^{42}$ Disponível em: http://www.sic.inep.gov.br/en/documents/doc_details/807-plano-de-acao-do-sem-20112015. Acesso em 27 out. 2011.
} 
incentivar a formação de parcerias para melhorar os sistemas educacionais e promover e fortalecer os programas de mobilidade tanto acadêmicos quanto profissionais. Nesse sentido, para promover a mobilidade de estudantes, docentes e pesquisadores entre os países, foi desenvolvido o Programa de Mobilidade Acadêmica Regional em Cursos Acreditados (MARCA). Nesse programa, os estudantes podem se candidatar a um intercâmbio de um semestre letivo em uma instituição de outro país e garantirem a validação de seu estudo na universidade de origem (http://portal.mec.gov.br/index.php? option $=$ com content $\&$ view $=$ article $\&$ id $=12285 \&$ ativo $=551 \&$ Itemid $=549$ ).

Outras iniciativas de política linguística no âmbito do MERCOSUL são o Grupo de Trabalho sobre Políticas Linguísticas (GTPL, no âmbito do SEM) e o Núcleo Disciplinario Enseñanza de Español y Portugués como Lenguas Segundas y Extranjeras (no âmbito da Associação de Universidades Grupo Montevidéu - AUGM), que reúnem especialistas dos diferentes países do bloco com o objetivo de discutir e propor ações de políticas linguísticas na Região. Na última reunião da XI Reunião do GTPL, ocorrida em Assunção (Paraguai) em abril/2011 $1^{43}$, o grupo analisou o plano operativo proposto em sua X Reunião, que define, dentre outros aspectos, a "identidade e função do GTPL" e o "funcionamento e atuação" do grupo"44. Dentre as metas do Plano de Trabalho 2011-2015, estabelecidas nesse documento, estão: promover e ampliar o ensino das línguas oficiais do MERCOSUL; rever os status das línguas no contexto regional; discutir a gestão da diversidade linguística e cultural nos sistemas educacionais dos países do Bloco.

\section{AÇÕES DE COOPERAÇÃO NA ÁREA EDUCACIONAL PARA A CONSTRUÇÃO DE UMA REGIÃO BILÍNGUE}

Em 30 de novembro de 2005 foi assinado entre os Ministérios da Educação da Argentina e do Brasil o Protocolo para a promoção e o ensino do espanhol e do português como segundas línguas. O protocolo firma a intenção de implementar programas de formação de ensino de idiomas, e estabelecer trabalho conjunto entre especialistas argentinos e brasileiros nas áreas de currículo, formação docente, educação a distância e elaboração de materiais didáticos, entre outros aspectos.

Em agosto de 2005, o Brasil promulgou a Lei n.16.161, que torna o espanhol língua de oferta obrigatória no ensino regular (Ensino Médio) do país a partir de 2010. Segundo Oliveira (2010), essa ação por parte do Brasil deu visibilidade ao espanhol no âmbito do MERCOSUL e favoreceu um novo posicionamento da Argentina com relação à gestão da língua. Indício desse fato é o CELU, gerado a partir de uma parceria entre universidades argentinas e brasileiras, conforme apresentado anteriormente. A

43 Ata disponível em: http://www.sic.inep.gov.br/en/documents/cat view/98-documentos-ereferencias/41-atas-de-reuniao--actas-de-reunion--minutes/53-ccr--ccr--rcc/62-gtpl--gtpl--wglp/218-2011. Acesso em 27 out. 2011.

${ }_{44}$ Ata disponível em: http://www.sic.inep.gov.br/en/documents/cat view/98-documentos-ereferencias/41-atas-de-reuniao--actas-de-reunion--minutes/53-ccr--ccr--rcc/62-gtpl--gtpl--wglp/217-2010. Acesso em 27 out. 2011. 
Argentina, em contrapartida, torna o português língua de oferta obrigatória na escola secundária pela Lei n. 26.468 de 17 de dezembro de $2008^{45}$.

O compromisso firmado entre os dois governos foi reforçado mais uma vez durante o Seminário Brasil-Argentina (evento destinado à consolidação das ações anteriormente citadas), ocorrido em 29 e 30 de novembro de 2007, denominado Ensino e certificação do Português e do Espanhol como segundas línguas. O evento reuniu professores universitários dos dois países com o objetivo de estabelecer prioridades de ações e fornecer subsídios para auxiliar na tomada de decisões dos governos relativas ao PELSE (Português e Espanhol como línguas segundas e estrangeiras). Foram discutidos a aplicação do Celpe-Bras e do CELU, o papel das universidades no ensino e difusão dessas línguas, a formação de professores e a elaboração de conteúdos.

\section{PROJETO ESCOLA INTERCULTURAL BILÍNGUE DE FRONTEIRA (PEIBF)}

O PEIBF, criado em 2005 como resultado de um acordo bilateral entre os governos brasileiro e argentino, tem por objetivo promover o intercâmbio entre professores dos países do MERCOSUL. No ano de 2008 o Projeto contava com catorze escolas (sete cidades) na fronteira Brasil-Argentina. No ano de 2009, foi ampliado para outros países do Bloco. Atualmente conta com 26 escolas, em cinco países (catorze escolas na fronteira Brasil-Argentina; seis na fronteira Brasil-Uruguai; duas na fronteira Brasil-Paraguai; quatro na fronteira Brasil-Venezuela) ${ }^{46}$.

O objetivo principal é a integração de estudantes e professores brasileiros com alunos e professores dos países vizinhos. Pelo menos uma vez por semana, os professores brasileiros cruzam a fronteira e vão lecionar em português para alunos hispanofalantes, ocorrendo o movimento inverso por parte dos professores falantes de espanhol. A metodologia adotada é a de ensino por projetos de aprendizagem, na qual os professores planejam as aulas juntos e definem em quais partes do projeto eles cruzarão a fronteira para ensinar. No PEIBF, o foco das práticas de ensino não é fazer aulas de português/espanhol, mas sim trabalhar conteúdos na língua do outro.

O I Seminário de Gestão em Educação Linguística de Fronteira no MERCOSUL (Foz do Iguaçu, julho/2011) foi ponto de encontro de vários professores/gestores de fronteira. Foram discutidas as dificuldades enfrentadas para a manutenção do PEIBF e a complexidade linguística dos contextos de fronteira (http://seminariogelf.blogspot.com/).

\footnotetext{
${ }^{45}$ Cristofoli (2010) analisa os avanços e dificuldades de implementação das decisões referentes às políticas públicas curriculares no âmbito das relações entre Brasil e Argentina (mais especificamente no Rio Grande do Sul e na Província de Córdoba). A autora aponta o lapso existente entre as políticas oficiais propostas e suas instâncias de implementação, expresso, entre outros aspectos, pela falta de planejamento na execução das políticas, pelos problemas de formação docente e pela falta de professores para que se possam colocar em prática as leis em ambos os países.

${ }^{46}$ Fonte: $\underline{\text { http:}: / \text { portal.mec.gov.br/index.php?Itemid=836\&id=12586\&option=com content\&view=article. }}$. Acesso em 24 out. 2011.
} 


\section{ASSOCIAÇÃO DE UNIVERSIDADES - GRUPO MONTEVIDÉU (AUGM)}

A AUGM, criada em 1991 e contemporânea do MERCOSUL, é uma organização civil não-governamental composta por universidades da Argentina, Bolívia, Brasil $^{47}$, Chile, Paraguai e Uruguai, que tem por diretriz manter um espaço de colaboração acadêmica comum.

Entre as ações previstas estão instrumentar cursos de pós-graduação que atendam às demandas científicas, profissionais e técnicas dos países envolvidos; promover programas interdisciplinares de investigação em temas básicos aplicados; promover planos que difundam as culturas dos seus povos, entre outras. Outro dos principais objetivos da Associação é promover ações de intercâmbio de estudantes e docentes, entre as quais estão os Programas ESCALA Docente e Estudantil, e também o Programa de Mobilidade de Pós-Graduação, lançado em 2011. Conforme já referido acima, o Núcleo de ensino de espanhol e português como línguas segundas e estrangeiras, criado em 2006, tem por função articular ações no âmbito acadêmico para o desenvolvimento de ensino, pesquisa e extensão envolvendo as duas línguas ${ }^{48}$.

\section{UNIVERSIDADE FEDERAL DA INTEGRAÇÃO LATINO-AMERICANA (UNILA)}

Surgindo como uma proposta para promover a cooperação e o intercâmbio do conhecimento e da cultura entre os países da América Latina, a UNILA propõe-se a uma política de educação bilíngue em português e espanhol voltada a questões do desenvolvimento latino-americano ${ }^{49}{ }^{50}$. Com sede em Foz do Iguaçu (Paraná), na fronteira tríplice Brasil-Argentina-Paraguai, a UNILA opera hoje em sede provisória no Parque Tecnológico de Itaipu. O plano inicial prevê a meta de ter dez mil alunos, 50\% brasileiros e $50 \%$ provenientes dos demais países da América Latina. O corpo docente deve contar com 250 professores brasileiros efetivos (selecionados por concurso público) e 250 professores-visitantes temporários, dos demais países (IMEA, 2009).

$\mathrm{Na}$ primeira fase do ensino de graduação, que começou em agosto de 2010, participaram quatro países (Brasil, Argentina, Uruguai e Paraguai), sendo disponibilizadas 300 vagas em seis cursos de graduação. Em 2011 foram oferecidas 600 novas vagas e disponibilizados mais seis cursos de graduação, totalizando doze cursos oferecidos. O processo de seleção também foi ampliado para outros países: Chile, Peru e Bolívia. Em nível de pós-graduação, os primeiros cursos foram oferecidos em 2011: o

\footnotetext{
${ }^{47}$ As universidades brasileiras integrantes são UNESP, UNICAMP, USP, UFMG, UFRGS, UFPR, UFSC, UFSM, UFG e UFSCar.

${ }^{48}$ Disponível em: http://www.grupomontevideo.edu.uy/index.php?view=category\&id=87\%3Alenguasextranjeras\&option $=$ com content\&Itemid=72\&lang=es. Acesso em 25 out 2011.

${ }^{49}$ Para obter maiores informações sobre a instituição, ver http://www.unila.edu.br/.

${ }^{50}$ Carvalho (em preparação) pesquisa o status das línguas na UNILA.
} 
Curso de Especialização em Literatura Latino-Americana e o de Energias Renováveis com ênfase em Biogás.

\section{CURSO DE ESPANHOL-PORTUGUÊS PARA INTERCÂMBIO (CEPI)}

O Projeto CEPI teve início em 2007, com a formação de uma equipe interinstitucional e interdisciplinar de pesquisadores e professores de Português e Espanhol como PLA e de Educação a Distância (EAD) de uma universidade brasileira, a Universidade Federal do Rio Grande do Sul (UFRGS), e duas argentinas, a Universidad Nacional de Cordoba (UNC) e a Universidad Nacional de Entre Ríos (UNER).

Consistindo em dois cursos de línguas estrangeiras a distância, um de espanhol e outro de português, o CEPI é uma ação de PPL cujo objetivo é promover a integração nos países do bloco através da inserção em práticas sociais e acadêmicas de alunos participantes de programas de mobilidade acadêmica no MERCOSUL e América Latina. Os materiais do CEPI de cada universidade são adaptados para o contexto local de cada Instituição (BULLA et al., 2009).

Além dos cursos de línguas para intercambistas, o projeto inclui um Curso de Formação de Professores CEPI (CFP-CEPI), também realizado em ambientes digitais, com os objetivos de preparar docentes para atuar com base no construto teórico do curso (SCHLATTER et al., 2009b) e elaborar materiais didáticos para a criação de seus CEPI institucionais. $\mathrm{O}$ trabalho interinstitucional do CEPI possibilita trocas entre professores e pesquisadores das universidades envolvidas, favorecendo a exploração de novas metodologias, recursos didáticos e tecnológicos para o ensino de línguas. Até o momento, foram oferecidos um CFP-CEPI (2009-2010), além de duas edições do CEPIPortuguês/UFRGS e do CEPI-Espanhol/UNC (2011), e uma edição do CEPIEspanhol/UNER (2011).

\section{CONSIDERAÇÕES FINAIS}

A projeção do Brasil na economia internacional e a consequente assinatura de acordos de cooperação econômica, científica e tecnológica com outros países têm impulsionado a expansão do mercado linguístico do português. Do mesmo modo, a dinâmica de tal mercado tem oportunizado o surgimento de contextos e ações que favorecem o surgimento de novos acordos e projetos de cooperação. Como vimos, a área de PLA se fortaleceu nos últimos 20 anos e tem apresentado crescimento significativo em grupos de trabalho e pesquisa no país e na Rede Brasileira de Ensino no Exterior.

O Celpe-Bras tem se firmado como instrumento linguístico promotor do status do português, não apenas por seu teor direcionador das práticas de ensino de PLA, mas também por seu caráter de afirmação simbólica do valor do idioma no mercado 
linguístico. Seu alcance também pode ser mensurado pelo fato de sua tecnologia ser parâmetro para a elaboração de outros exames de proficiência e de materiais didáticos. Nesse sentido, destacamos o papel do professor, à medida que sua atuação é fundamental na implementação (e sucesso) de políticas linguísticas. Essa constatação aponta para a importância de investir em formação docente para que uma política alcance o resultado desejado.

$\mathrm{Na}$ área teórica de Linguística Aplicada e PPL, pesquisas sobre o exame têm dado visibilidade ao impacto que podem exercer as ações de PPL no status das línguas e nas práticas de ensino. Além disso, a projeção da área de PLA e do Celpe-Bras tem estimulado a produção de conhecimento sobre ensino, aprendizagem e avaliação. Algumas iniciativas apresentadas evocam a noção de agência, denotando que a planificação linguística depende, em grande parte, da apropriação das políticas linguísticas pelos atores envolvidos, deslocando o foco das políticas macrolinguísticas. Julgando que as PPL de aquisição estão interligadas e têm efeito sobre as PPL de corpus e status, pode-se considerar que as ações na área do ensino são essenciais na gestão das línguas.

Buscamos apresentar, neste artigo, um panorama de ações de promoção internacional do português ${ }^{51}$, com foco nas iniciativas ligadas ao ensino, à pesquisa e ao estabelecimento de parâmetros de proficiência de língua adicional, procurando levantar possíveis relações entre essas ações e o status da língua portuguesa. Entendemos que a PPL, como área teórica, pode servir de instrumento de análise e de proposição de ações sobre as línguas/linguagens, ajudando a compreender como se relacionam entre si e com outras ações e movimentos sociais e, dessa forma, sustentar a busca por soluções adequadas para seu gerenciamento.

\section{REFERÊNCIAS}

ANDRIGUETTI, Graziela. A elaboração de tarefas de compreensão oral para o ensino de português como língua adicional em níveis iniciais. 2009. 194 p. Dissertação (Mestrado em Linguística Aplicada) - Instituto de Letras, UFRGS, Porto Alegre, RS.

\footnotetext{
${ }^{51}$ Dentre algumas das ações de PPL não contempladas neste texto, citamos: a) a criação da Comissão para Definição da Política de Ensino-Aprendizagem, Pesquisa e Promoção da Língua Portuguesa (COLIP), em 2005 (http://portal.mec.gov.br/sesu/arquivos/pdf/portarias/portariacolip-4056.pdf); b) o "Programa Linguagem das Letras e dos Números", programa de cooperação educacional, criado em 2008, entre o Brasil e países africanos da CPLP (países participantes: Cabo Verde, desde 2008; Guiné-Bissau, desde 2011; prevista a inclusão de Angola e São Tomé e Princípe em 2012) e cujo objetivo é auxiliar na capacitação profissional de professores de Português e Matemática daqueles países (http://desimbloglio.blogspot.com/2011/07/160-professores-do-ensino-medio-de.html); c) as políticas linguísticas do Uruguai para a construção e manutenção de um ambiente bilíngue espanhol-português (BROVETTO et al., 2007; BORTOLINI, 2009) e o acordo bilateral assinado em 2005 para a criação de Escolas/Institutos Técnicos Binacionais Fronteiriços Profissionais (BRASIL-MRE, 2011); e d) ações no Paraguai, como a atuação da Embaixada Brasileira em Assunção na área de PLA e a elaboração do Dicionário Trilíngue Español-Português-Guarani, no âmbito do Projeto Avakotepa, criado para constituir um corpus oral e escrito da língua guarani contemporânea (http://avakotepa.blogspot.com/).
} 
BALDAUF JR, Richard. Rearticulating the Case for Micro Language Planning in a Language Ecology Context. Current Issues in Language Planning, v.2, n.7, p. 147-170, 2006.

BONINO, Rachel. I love português. Revista Língua Portuguesa, São Paulo, $\mathrm{n}^{0}$ 24, out 2007. Disponível em: http://revistalingua.uol.com.br/textos.asp?codigo=11408. Acesso em 15 out. 2011.

BORTOLINI, Letícia. Letramento em uma escola de educação bilíngue na fronteira Uruguai/Brasil. 2009. 203 p. Dissertação (Mestrado em Linguística Aplicada) Instituto de Letras, UFRGS, Porto Alegre, RS.

BOURDIEU, Pierre. A economia das trocas linguísticas. São Paulo: Edusp, 1998.

BRASIL. MINISTÉRIO DA EDUCAÇAO E CULTURA. Secretaria de Educação Superior. Certificado de Proficiência em Língua Portuguesa para Estrangeiros: Manual do Candidato. Brasília: MEC, 2006.

BRASIL. MINISTÉRIO DAS RELAÇÕES EXTERIORES. Balanço de política externa 2003-2010. Brasília: MRE, 2011. Disponível em http://www.itamaraty.gov.br/temas/balanco-de-politica-externa-2003-2010. Acesso em 28 out. 2011.

BROVETTO, Claudia; GEYMONAT, Javier; BRIAN, Nicolás (Orgs.). Portugués del Uruguay y educación bilingüe. Montevideo: ANEP-CEP, 2007.

BULLA, Gabriela. A realização de atividades pedagógicas colaborativas em sala de aula de Português como língua estrangeira. 2007. 128 p. Dissertação (Mestrado em Linguística Aplicada) - Instituto de Letras, UFRGS, Porto Alegre, RS.

BULLA, Gabriela; GARGIULO, Hebe; SCHLATTER, Margarete. Organización general de materiales didácticos para la enseñanza online de las lenguas: el caso del Curso de Español-Portugués para el Intercambio (CEPI). II Jornadas Internacionales de Tecnologías Aplicadas a la Enseñanza de Lenguas. Universidad Nacional de Córdoba, Córdoba, 2009, v. CD. p. 01-12.

CALVET, Louis-Jean. As politicas linguísticas. São Paulo: Parábola, 2007

CARVAlHO, Simone da Costa. Políticas Linguísticas no Brasil. 2007. Trabalho de Conclusão de Curso (Graduação em Letras) - Instituto de Letras, UFRGS, Porto Alegre, RS.

- O status das línguas na Universidade Federal da Integração LatinoAmericana. Dissertação em preparação (Mestrado em Linguística Aplicada) - Instituto de Letras, UFRGS, Porto Alegre, RS.

COELHO DE SOUZA, José. A canção popular brasileira no ensino de português como língua adicional na perspectiva de gêneros do discurso. Dissertação em preparação (Mestrado em Linguística Aplicada) - Instituto de Letras, UFRGS, Porto Alegre, RS.

COOPER, Robert. Language planning and social change. Avon: Cambridge University Press, 1989. 
COSTA, Everton Vargas da. Formação em serviço de professores de português como língua adicional. Pesquisa em andamento (Mestrado em Linguística Aplicada) Instituto de Letras, UFRGS, Porto Alegre, RS.

CRISTOFOLI, Maria Silvia. Políticas de línguas estrangeiras na educação básica: Brasil e Argentina entre avanço, percalços. 2010. 223 p. Tese (Doutorado em Educação) - Faculdade de Educação, UFRGS, Porto Alegre, RS.

DINIZ, Leandro Alves. Políticas de línguas em livros didáticos brasileiros de ensino de português como língua estrangeira. In: ZOPPI FONTANA, Mónica (Org.). O português do Brasil como língua transnacional. Campinas: Editora RG, 2009, p. 59-77.

- Política linguística do Estado brasileiro na Contemporaneidade: a institucionalização de mecanismos de promoção da língua nacional no exterior. Tese em preparação (Doutorado em Linguística) - Instituto de Estudos da Linguagem, Unicamp, Campinas.

DUARTE, Andrea Belfort. O ensino de PBE no mundo dos negócios: gêneros textuais e escrita. 2009. 122 p. Dissertação (Mestrado em Letras). Universidade Federal Fluminense, Rio de Janeiro.

FARACO, Carlos Alberto. A lusofonia: impasses e perspectivas. Texto apresentado no Simpósio Políticas e ideologías en la legitimación de las lenguas internacionales. $8^{\circ}$ Congreso de Linguística General da Universidad Autónoma de Madrid. 26 jun. 2008.

- A língua portuguesa no contexto internacional: perspectivas e impasses. Conferência proferida no Colóquio Português em contexto africano multilíngue: em busca de consensos. UEM, Moçambique, 15 set. 2011. Disponível em: http://www.catedraportugues.uem.mz/lib/docs/Faraco_Coloquio.pdf. Acesso em 20 out. 2011.

FOREQUE, Flávia. Português é POP. Folha de São Paulo, São Paulo, 16/10/2011. Disponível em: http://acervo.folha.com.br/fsp/2011/10/16/10. Acesso em 28 out. 2011.

FORTES, Melissa. Uma compreensão etnometodológica do trabalho de fazer ser membro na fala-em-interação de entrevista de proficiência de português como língua adicional. 2009. 353 p. Tese (Doutorado em Estudos da Linguagem) - Instituto de Letras, UFRGS, Porto Alegre, RS.

FURTOSO, Viviane Bagio (Org.). Formação de professores de Português para Falantes de Outras Línguas: reflexões e contribuições. Londrina: EDUEL, 2009. v.1.

- Desempenho oral em Português para Falantes de Outras Linguas: da avaliação à aprendizagem de línguas estrangeiras em contexto online. 2011. 284 p. Tese (Doutorado em Estudos Linguísticos). UNESP, São José do Rio Preto, SP.

GARCÍA, Ofelia; MENKEN, Kate. Stirring the onion: educators and the dynamics of language education policies. In: (Eds.). Negotiating language policies in schools: educators as policy makers. New York: Routledge, 2010, p. 249-261.

GOMES, Maíra. A complexidade de tarefas de leitura e produção escrita no exame Celpe-Bras. 2009. 142 p. Dissertação (Mestrado em Linguística Aplicada) - Instituto de Letras, UFRGS, Porto Alegre, RS. 
GRAYLEY, Monica Villela; CAETANO, João. O português no mundo, três anos depois. Radiotelevisão Caboverdeana. Cabo Verde, 25 jul. 2011. Disponível em http://www.rtc.cv/index.php?paginas=21\&id_cod=2927. Acesso em 20 out. 2011.

GUERREIRO, Carmen; PEREIRA JUNIOR, Luiz. O valor do idioma. Crescimento e valorização do português no mundo acompanham atual destaque econômico e cultural do Brasil. Revista Língua Portuguesa, São Paulo, no 72, out 2011. Disponível em: http://revistalingua.uol.com.br/textos.asp?codigo=12426. Acesso em $10 \mathrm{de} \mathrm{dez.} 2011$.

HAUGEN, Einar. Linguistics and Language Planning. In: BRIGHT, William (Org.). Sociolinguistics. La Haye: Mouton, 1966.

HORNBERGER, Nancy. Frameworks and Models in Language Policy and Planning. In: RICENTO, Thomas (Ed.). An introduction to language policy: Theory and method. Oxford, Blackwell Publishing, 2006, p. 10-23.

IMEA. Instituto MERCOSUL de Estudos Avançados. A UNILA em construção. Publicações IMEA, 2009.

JOHNSON, David Cassels. Ethnography of Language Policy. Language Policy Journal, Springer Netherlands Publisher, vol. 8, n. 2, p. 139-159, 2009.

LI, Ye. Pressupostos teóricos e culturais para um curso de preparação para o exame Celpe-Bras para alunos chineses. 2009. 131 p. Dissertação (Mestrado em Letras) Instituto de Letras, UFRGS, Porto Alegre.

MENDES, Edleise (Org.). Diálogos Interculturais:Ensino e Formação em Português Lingua Estrangeira. $1^{\text {a }}$ ed. Campinas: Pontes, 2011. v. 1.

OHLWEILER, Beatriz Demoly. Criação de um jornal na sala de aula de português língua estrangeira. 2006. 104 p. Dissertação (Mestrado em Linguística Aplicada). Instituto de Letras, UFRGS, Porto Alegre.

OLIVEIRA, Gilvan Müller de. Política Lingüística, Política Historiográfica: Epistemologia e escrita da História da(s) Lingua(s) a propósito da língua portuguesa no Brasil Meridional (1754-1830). 2004. 220 p. Tese (Doutorado em Linguística) Instituto de Estudos da Linguagem, Unicamp, Campinas.

. O lugar das línguas: A América do Sul e os mercados linguísticos na Nova Economia. Synergies Brésil, $\mathrm{n}^{\circ}$ spécial 1, p. 21-30, 2010. Disponível em http://ressources-cla.univ-fcomte.fr/gerflint/BresilSPECIAL1/gilvan.pdf. Acesso em 25 out. 2011.

. O português do século XXI e suas políticas linguísticas. Conferência proferida no Congresso da Sociedade Internacional de PLE (CONSIPLE-2011), Paraguai, Assunção, 06 out. 2011.

RAMOS, Ingrid Frank de. Constituição e superação de momentos desconfortáveis em sequências de convites à participação: a construção do engajamento na fala-eminteração de sala de aula. 2010. 170 p. Dissertação (Mestrado em Linguística Aplicada) - Instituto de Letras, UFRGS, Porto Alegre, RS.

RICENTO, Thomas. 2000. Historical and theoretical perspectives in language policy and planning. Journal of Sociolinguistics, vol. 4, n. 2, p. 196-213, 2000. 
Theoretical perspectives in language policy: an overview. In: (Ed.). $A n$ introduction to language policy: Theory and method. Oxford: Blackwell Publishing, 2006, p. 3-9.

RODRIGUES, Meirelen. O exame Celpe-Bras: reflexões teórico-didáticas para o professor de português para falantes de outras línguas. 2006. 100 p. Dissertação (PósGraduação em Linguística Aplicada) - Instituto de Estudos da Linguagem, Unicamp, Campinas.

SANTOS, Letícia. Avaliação de desempenho para o nivelamento de alunos de português língua estrangeira. 2007. 179 p. Dissertação (Mestrado em Linguística Aplicada) - Instituto de Letras, UFRGS, Porto Alegre, RS.

SCARAMUCCI, Matilde. O exame Celpe-Bras: impactos nas percepções de professores e candidatos em contextos de PLE. Congresso Internacional de Política Linguística na América do Sul, 2006, João Pessoa. Língua(s) e povos: unidade e diversidade. João Pessoa: Idéia, 2006. p. 270-276.

SCHLATTER, Margarete. O sistema de avaliação Celpe-Bras: características, implementação e perspectivas. Congresso Internacional de Política Linguística na América do Sul, 2006, João Pessoa. Língua(s) e povos: unidade e diversidade. João Pessoa: Idéia, 2006. p. 171-175.

SCHLATTER, Margarete; BULLA, Gabriela; JURIC, Victor; HRASTE, Margarida; RODRIGUEZ, Maria Laura. A certificação espanhol/português para intercâmbio (CEPI) como uma ação de política linguística no âmbito do Mercosul. III Encuentro Internacional de Investigadores de Políticas Linguísticas. AUGM, Universidade Nacional de Córdoba, out 2007, p. 53-58.

SCHLATTER, Margarete; SCARAMUCCI, Matilde; PRATI, Silvia; ACUÑA, Leonor. Celpe-Bras e CELU: Impactos da construção de parâmetros comuns de avaliação de proficiência em português e espanhol. In: ZOPPI FONTANA, Mónica (Org.). $O$ português do Brasil como língua transnacional. Campinas, SP: Editora RG, 2009a, p. 95-122.

SCHLATTER, Margarete; BULLA, Gabriela; GARGIULO, Hebe; JURIC, V. S. La Formación del profesor CEPI para interactuar en una comunidad colaborativa de aprendizaje a distancia. II Jornadas de Tecnologías aplicadas a la Enseñanza de las Lenguas. Universidad Nacional de Córdoba, Córdoba, 2009b, v. CD. p. 18.

SCHLATTER, Margarete; GARCEZ, Pedro M. Línguas adicionais (Espanhol e Inglês). In: RIO GRANDE DO SUL, Secretaria de Estado da Educação, Departamento Pedagógico. Referenciais curriculares do Estado do Rio Grande do Sul: linguagens, códigos e suas tecnologias. Porto Alegre: SE/DP, 2009. p. 127-172. Disponível em http://www.seduc.rs.gov.br/pse/html/refer_curric.jsp?ACAO=acaol. Acesso em 30 out. 2011.

SCHOFFEN, Juliana. Avaliação de proficiência oral em lingua estrangeira: descrição dos niveis de candidatos falantes de espanhol no exame Celpe-Bras. 2003. 101 p. Dissertação (Mestrado em Linguística Aplicada) - Instituto de Letras, UFRGS, Porto Alegre, RS. 
. Gêneros do discurso e parâmetros de avaliação de proficiência em português como língua estrangeira no exame Celpe-Bras. 2009. 192 p. Tese (Doutorado em Linguística Aplicada). Instituto de Letras, UFRGS, Porto Alegre, RS.

SIDI, Walkiria. Niveis de proficiência em leitura e escrita de falantes de espanhol no exame CELPE-Bras. 2002. 71 p. Dissertação (Mestrado em Linguística Aplicada) Instituto de Letras, UFRGS, Porto Alegre, RS.

SIMÕES, Alex Neris. Blogosfera PLE. Dissertação em preparação (Mestrado em Letras). Universidade Federal da Bahia.

TORQUATO, Clóris. Politicas linguísticas desenvolvidas em Cabo Verde (África). 2009. 220 p. Tese (Doutorado em Linguística) - Instituto de Estudos da Linguagem, Unicamp, Campinas, SP.

ZOPPI FONTANA, Mónica. O português do Brasil como língua transnacional. In:_ (Org.). O português do Brasil como língua transnacional. Campinas: Editora RG, 2009, p. 13-41.

YAN, Qiaorong. De práticas sociais a gêneros do discurso: uma proposta para o ensino de português para falantes de outras línguas. 2008. 132 p. Dissertação (Mestrado em Linguística Aplicada) - Instituto de Letras, UFRGS, Porto Alegre, RS. 